\title{
Secondary Metabolites from Pterocaulon alopecuroides and their Antiproliferative Activities
}

\author{
Quírico A Castillo ${ }^{1, *}$, José M. Padrón², Anastacio Emiliano³
}

Quírico A Castillo ${ }^{1, *}$, José M. Padrón ${ }^{2}$, Anastacio Emiliano $^{3}$

'Escuela de Química and Instituto de Química, Universidad Autónoma de Santo Domingo (UASD), Facultad de Ciencias, Ciudad Universitaria, Santo Domingo, D.N., DOMINICAN REPUBLIC. 'BioLab, Instituto Universitario de Bio-Orgánica "Antonio González" (IUBO-AG), Centro de Investigaciones Biomédicas de Canarias (CIBICAN), Universidad de La Laguna, 38206, La Laguna, SPAIN.

${ }^{3}$ Universidad Ana G. Méndez at Gurabo, PO Box 3030, Gurabo, PR 00778, PUERTO RICO.

Correspondence

Dr. Quírico A. Castillo

Escuela de Química and Instituto de Química, Universidad Autónoma de Santo Domingo (UASD), Facultad de Ciencias, Ciudad Universitaria, Santo Domingo, D.N., DOMINICAN REPUBLIC.

Phone no : +1 8095358273

E-mail: qcastillo55@uasd.edu.do

\section{History}

- Submission Date: 05-11-2018;

- Review completed: 03-01-2019;

- Accepted Date: 21-01-2019

DOI : 10.5530/pj.2019.11.78

Article Available online

http://www.phcogj.com/v11/i3

\section{Copyright}

() 2019 Pharmacognosy Journal. This is an open-access article distributed under the terms of the Creative Commons Attribution 4.0 International license.

\begin{abstract}
Objective: To isolate secondary metabolites from the aerial parts of Pterocaulon alopecuroides, elucidate their structures and evaluate their antiproliferative activities on selected human cancer cell lines. Materials and Methods: The ethanolic extract of $P$. alopecuroides afforded five compounds, which were characterized using spectroscopic techniques and by comparison with data from the literature. Antiproliferative activities of all isolates were evaluated. Results: The compounds 7-(2,3-dihydroxy-3-methylbutoxy)-6-methoxycoumarin (1), 5,6-methylenedioxy-7-(2,3-dihydroxy-3-methylbutoxy) coumarin (2), Dihydrokaempferol (3), 5,7,4'-trihydroxy6 -( $\alpha, \alpha$-dimethylallyl)dihydroflavonol (4) and 5,4'-dihydroxy-7- $(\gamma, \gamma-$-dimethylallyloxy)dihydroflavonol (5) were isolated. The antiproliferative activity of all compounds was evaluated in a panel of six human solid tumor cell lines showing $\mathrm{GI}_{50}$ values for the most active compounds in the low micromolar range. Conclusion: Compound $\mathbf{2}$ is reported for first time from $P$. alopecuroides. Isolated coumarins show no antiproliferative activity, whilst among flavonoids compound $\mathbf{5}$ showed the best antiproliferative activity.

Key words: Pterocaulon alopecuroides, Coumarins, Flavonoids, Antiproliferative activities, 5,4'-dihydroxy-7-( $\gamma, \gamma$-dimethylallyloxy) dihydroflavonol.
\end{abstract}

\section{INTRODUCTION}

The genus Pterocaulon (Asteraceae) has 18 species, of which twelve are American and six are Australian. ${ }^{1}$ Two of them are present in the island of Hispaniola: P. alopecuroides and P. virgatum. ${ }^{2}$

Continuing our interest in studying the flora present in Hispaniola, the phytochemical study of the species Pterocaulon alopecuroides (Lam.) DC. was carried out, which led to the isolation and structure elucidation of compounds 1-5. To the best of our knowledge, this is the first time that compound $\mathbf{2}$ is reported to be isolated from $P$. alopecuroides.

\section{MATERIALS AND METHODS}

\section{General}

NMR spectra were recorded using a Bruker Ascend Aeon spectrometer with cryoprobe operating at $400 \mathrm{MHz}$ in ${ }^{1} \mathrm{H}$ and $100 \mathrm{MHz}$ in ${ }^{13} \mathrm{CNMR}$ respectively. The chemical shift $(\delta)$ values are given in ppm and coupling constants $(J)$ are given in $\mathrm{Hz}$. $\mathrm{CDCl}_{3}$ or $\left(\mathrm{CD}_{3}\right)_{2} \mathrm{CO}$ were used as solvents. Column chromatography was performed on a Biotage Isolera One flash purification system (Biotage, Charlotte, North Carolina, USA) using SNAP ULTRA silica gel cartridges. Analytical and preparative TLC were developed on silica gel $60 \mathrm{~F}_{254}$ plates (Merck KGaA, Darmstadt, Germany).

\section{Plant Material}

Aerial parts of $P$. alopecuroides were collected on October 2015 at Cordillera Central, Municipio Rancho Arriba, San José de Ocoa province, Dominican Republic. The plant material was identified by Teodoro Clase, botanist at Jardín Botánico Nacional “Dr. Rafael Ma. Moscoso", Santo Domingo, Dominican Republic, where a voucher specimen (JBSD 126571) has been deposited.

\section{Extraction and Isolation}

Aerial parts of $P$. alopecuroides were air-dried and ground to a fine powder. The ground material (105 g) was extracted with $95 \%$ EtOH using a Soxhlet apparatus. The resulting crude extract (18.5 g) was dissolved in $95 \% \mathrm{EtOH}(250 \mathrm{~mL})$ and treated with a $5 \% \mathrm{~Pb}(\mathrm{OAc})_{2}$ solution $(250 \mathrm{~mL})$ to precipitate chlorophyll. After $24 \mathrm{~h}$, the mixture was filtered, concentrated in vacuo to remove most of the $\mathrm{EtOH}$ and extracted successively with hexanes, $\mathrm{Et}_{2} \mathrm{O}$ and AcOEt $(3 \times 500 \mathrm{~mL}$ each $)$. The $\mathrm{Et}_{2} \mathrm{O}$ residue $(2 \mathrm{~g})$ was subjected column chromatography, eluting with mixtures of hexanes-acetone with increasing polarity to afford 40 fractions. Repeated column chromatography, followed by PTLC afforded compounds 1-5.

\section{Antiproliferative assays}

The cell lines used in this study were A549 and SW1573 (lung), HBL-100 and T-47D (breast), HeLa (cervix) and WiDr (colon) and were a kind gift of 


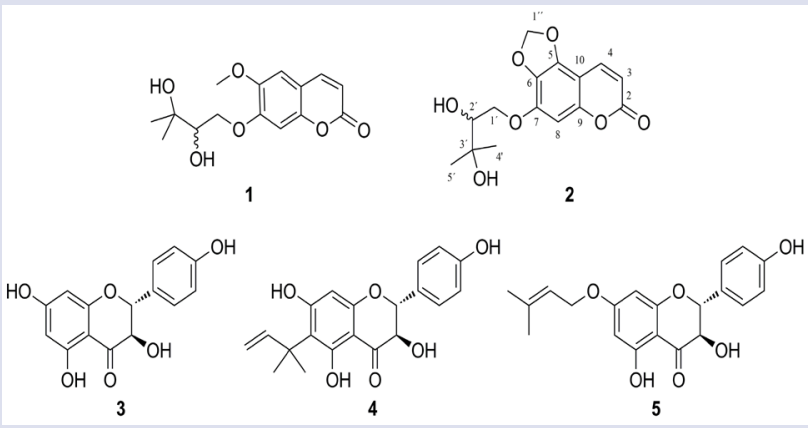

Figure 1: Compounds 1-5 isolated from the aerial parts of Pterocaulon alopecuroides.
Table 1: Antiproliferative Activity $\left(\mathrm{Gl}_{50}\right)$ of compounds 1-5 against Human Solid Tumor Cells ${ }^{a}$.

\begin{tabular}{ccccccc}
\hline Compound & A549 & $\begin{array}{r}\text { HBL- } \\
100\end{array}$ & SW1573 & HeLa & T-47D & WiDr \\
\hline $\mathbf{1}$ & $>100$ & $>100$ & $>100$ & $>100$ & $>100$ & $>100$ \\
$\mathbf{2}$ & $>100$ & $>100$ & $>100$ & $>100$ & $>100$ & $>100$ \\
$\mathbf{3}$ & $31 \pm 6.0$ & $55 \pm 8.2$ & $27 \pm 4.2$ & $32 \pm 5.6$ & $31 \pm 2.6$ & $35 \pm 6.2$ \\
$\mathbf{4}$ & $33 \pm 3.7$ & $>100$ & $40 \pm 7.3$ & $82 \pm 20$ & $20 \pm 7.6$ & $18 \pm 4.1$ \\
$\mathbf{5}$ & $16 \pm 0.9$ & $20 \pm 0.6$ & $17 \pm 0.3$ & $16 \pm 1.6$ & $17 \pm 1.0$ & $19 \pm 2.2$ \\
\hline
\end{tabular}

aValues are given in $\mu \mathrm{M}$ and are means of two to three experiments.

reported for first time as isolated from this species. The study of the antiproliferative activity against selected human solid tumor cell lines showed that the isolated coumarins $(\mathbf{1}, 2)$ were not active, while the isolated flavonoids (3-5) were more active, being compound 5 the most active of all the ones tested with $\mathrm{GI}_{50}$ values ranging from 16 to $20 \mu \mathrm{M}$.

\section{ACKNOWLEDGEMENT}

This project has been partially supported by the program FONDOCYT of the Ministerio de Educación Superior, Ciencia y Tecnología (MESCYT), Dominican Republic (Grant 2014-1D4-02). QAC thanks Dr. Ernesto Abel-Santos (University of Las Vegas, Nevada, USA) for his help in this project.

\section{CONFLICT OF INTEREST}

the authors declare no conflict of interest.

\section{ABBREVIATIONS}

EtOH: Ethyl Alcohol; $\mathbf{P b}(\mathbf{O A c})_{2}$ : Lead Acetate; $\mathbf{E t}_{2} \mathbf{O}$ : Ethyl Ether; AcOEt: Ethyl Acetate; PTLC: Preparative Thin Layer Chromatography.

\section{REFERENCES}

\section{5,6-methylenedioxy-7-(2,3-dihydroxy-3-methylbutoxy) coumarin (2)}

White solid; ${ }^{1} \mathrm{H}$ NMR $\left(400 \mathrm{MHz}, \mathrm{CDCl}_{3}\right) \delta=7.97(1 \mathrm{H}, \mathrm{d}, J=9.7, \mathrm{H}-4)$ $6.58(1 \mathrm{H}, \mathrm{s}, \mathrm{H}-8), 6.24(1 \mathrm{H}, \mathrm{d}, J=9.7, \mathrm{H}-3), 6.04\left(2 \mathrm{H}, \mathrm{s}, \mathrm{H}-1^{\prime \prime}{ }^{\prime}\right), 4.51(1 \mathrm{H}$, dd, $\left.J=10.3,2.9, \mathrm{H}^{-1}{ }^{\prime} \mathrm{a}\right), 4.38\left(1 \mathrm{H}, \mathrm{dd}, J=10.3,8.0, \mathrm{H}-1^{\prime} \mathrm{b}\right), 3.83(1 \mathrm{H}$, m, H-2'), $1.33\left(3 \mathrm{H}, \mathrm{s}, \mathrm{H}_{3}-4^{\prime}\right), 1.28\left(3 \mathrm{H}, \mathrm{s}, \mathrm{H}_{3}-5^{\prime}\right) .{ }^{13} \mathrm{C} \mathrm{NMR}(100 \mathrm{MHz}$, $\left.\mathrm{CDCl}_{3}\right) \delta=161.2(\mathrm{C}-2), 152.5(\mathrm{C}-7), 151.5(\mathrm{C}-9), 138.6(\mathrm{C}-4), 136.7$ (C-5), 132.3 (C-6), 112.1 (C-3), 106.9 (C-10), 102.1 (C-1' '), 93.1 (C-8), 76.4 (C-2'), 73.7 (C-1'), 71.6 (C-3'), 26.7 (C-4'), 24.8 (C-5'). Assignments were confirmed by HSQC-DEPT and HMBC experiments.

\section{Antiproliferative activity}

All isolates were evaluated for their antiproliferative activity against the human solid tumor cell lines A549, HBL-100, HeLa, SW1573, T-47D and WiDr. The bioactivity of compounds 1-5 on the mentioned cell lines was expressed as $\mathrm{GI}_{50}$. The results (Table 1) shows that coumarins 1-2 are inactive whilst flavonoids 3-5 display growth inhibition. The most active compound of the series is flavonoid $\mathbf{5}$, which show $\mathrm{GI}_{50}$ values in the range $16-20 \mu \mathrm{M}$

\section{CONCLUSION}

In summary, we have reported the isolation of five secondary metabolites from the aerial parts of Pterocaulon alopecuroides. Compound $\mathbf{2}$ is
1. Cabrera AL, Ragonese AM. Revisión del género Pterocaulon (Compositae). Darwiniana. 1978;21(2-4):185.

2. Liogier AH. La flora de la Española VIII. $1^{\text {st }}$ ed. San Pedro de Macorís: Universidad Central del Este. 1996.

3. Castillo QA, Triana J, Eiroa JL, Padrón JM, Plata GB, Abel-Santos EV, Báez LA, et al. Flavonoids from Eupatorium Illitum and Their Antiproliferative Activities. Phcog J. 2015;7(3):178-81.

4. Monks A, Scudiero D, Skehan P, Shoemaker R, Paull K, Vistica D, Hose C, et al. Feasibility of High Flux Anticancer Drugs Screen Using a Diverse Panel of Cultured Human Tumor Cell Lines. J Natl Cancer Inst. 1991;83(11):757-66.

5. Stadler M, Padrón JM, González-Cardenete MA. Antiproliferative Activity and Effect on GABAA Receptors of Callitrisic Acid Derivatives. Planta Med Int Open. 2017:4:e89-92.

6. Vilegas W, Boralle N, Cabrera A, Bernardi AC, Pozetti GL, Arantes SF Coumarins and A Flavonoid from Pterocaulon alopecuroides. Phytochemistry. 1995;38(4):1017-9.

7. Magalhaes AF, Magalhaes EG, Leitao FHF, Frighetto RTS, Barros SMG. Coumarins from Pterocaulon balansae and P. lanatum. Phytochemistry. 1981;20(6):1369-71.

8. Alarcón R, Pacciaroni A, Peñaloza L, Uriburu ML, Boemo A, Sosa V. Phenolic compounds from Pterocaulon alopecuroides. Biochem Syst Ecol. 2010;38(5):1059-64.

9. Alarcón R, Carrizo FR, Ocampos S, Lucatti A, Flores GL, Tonn C, et al. Flavonoids from Pterocaulon alopecuroides with Antibacterial Activity. Planta Med. 2008;74(12):1463-7. 
GRAPHICAL ABSTRACT

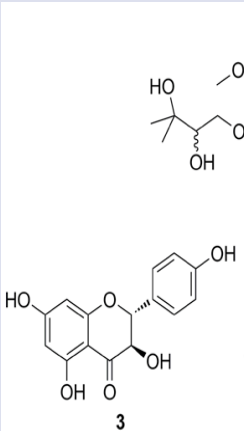

3<smiles>C=CC(C)(C)c1c(O)cc2c(c1O)C(=O)[C@H](O)[C@@H](c1ccc(O)cc1)O2</smiles>
5

\section{SUMMARY}

- Phytochemical investigation of the ethanolic extract of the aerial parts of Pterocaulon alopecuroides (Asteraceae) afforded the compounds 7-(2,3-dihydroxy-3-methylbutoxy)-6-methoxycoumarin (1), 5,6-methylenedioxy7-(2,3-dihydroxy-3-methylbutoxy) coumarin (2), Dihydrokaempferol (3), 5,7,4'-trihydroxy-6-( $\alpha, \alpha$-dimethylallyl)dihydroflavonol (4) and 5,4'-dihydroxy-7$(v, y$-dimethylallyloxy)dihydroflavonol (5). All isolates were evaluated for their antiproliferative activities on a panel of six human tumor cell lines. Compound 2 is reported for first time from $P$. alopecuroides.

\section{ABOUT AUTHORS}

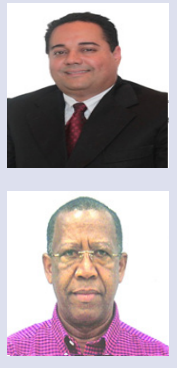

Quírico A. Castillo: Professor of Organic Chemistry. Universidad Autónoma de Santo Domingo, Dominican Republic.

Anastacio Emiliano: Professor of Organic Chemistry. Universidad Ana G. Méndez, Gurabo, Puerto Rico.

Cite this article: Castillo QA, Padrón JM, Emiliano A. Secondary Metabolites from Pterocaulon alopecuroides and their Antiproliferative Activities. Pharmacog J. 2019;11(3):493-5. 